Research article

Open Access

\title{
Simultaneous Quantitative Determination of Metoprolol, Atorvastatin and Ramipril in Capsules by a Validated Stability-Indicating RP-UPLC Method
}

${ }^{1}$ Analytical Research and Development, Integrated Product Development, Dr. Reddy's Laboratories Ltd., Bachupally, Hyderabad-500 072, India.

${ }^{2}$ Department of Chemistry, Rayalaseema University, Kurnool-518002, A.P., India.

* Corresponding author. E-mail: rajakumars@drreddys.com (R. K. Seshadri)

Sci Pharm. 2010; 78: 821-834

doi:10.3797/scipharm.1004-14

Published: $\quad$ August $24^{\text {th }} 2010$

Accepted: $\quad$ August $24^{\text {th }} 2010$

Received: $\quad$ April $18^{\text {th }} 2010$

This article is available from: http://dx.doi.org/10.3797/scipharm.1004-14

(c) Seshadri et al.; licensee Österreichische Apotheker-Verlagsgesellschaft m. b. H., Vienna, Austria.

This is an Open Access article distributed under the terms of the Creative Commons Attribution License (http://creativecommons.org/licenses/by/3.0/), which permits unrestricted use, distribution, and reproduction in any medium, provided the original work is properly cited.

\begin{abstract}
A simple ultra performance liquid chromatographic (UPLC) method has been developed for the simultaneous estimation of Metoprolol (MT), Atorvastatin (AT) and Ramipril (RM) from capsule dosage form. The method was developed using Zorbax® XDB-C18 $(4.6 \mathrm{~mm} \times 50 \mathrm{~mm}, 1.8 \mu \mathrm{m})$ column with a mobile phase consisting of $0.06 \%$ ortho phosphoric acid in Milli $Q \circledR$ water having an ion pair reagent, $0.0045 \mathrm{M}$ Sodium lauryl sulphate as buffer, at ratio of buffer: Acetonitrile $(50: 50 \mathrm{v} / \mathrm{v})$, at $55^{\circ} \mathrm{C}$ column temperature with a flow rate of 1.0 $\mathrm{ml} / \mathrm{min}$. Detection was carried out with ultra-violet detection at $210 \mathrm{~nm}$ for RM, MT and AT respectively. The retention times were about 1.3, 2.1 and 2.6 min for MT, AT and RM respectively, the method was validated for linearity, accuracy, precision, specificity, robustness and ruggedness. The \% mean recoveries are 101.9, 102.1 and 101.4 for MT, AT and RM respectively. The method was found to be rugged and robust and can be successfully used to determine the three drugs and its combinations.
\end{abstract}

\section{Keywords}

Fixed-dose combination • Chromatography $\cdot$ Method Validation • Reviro $\bullet$ Impurities 


\section{Introduction}

Ramipril (RM) is a potent and specific angiotensin-converting enzyme (ACE) inhibitor that catalyzes the conversion of angiotensin I to the vasoconstrictor substance, angiotensin II which also simulates the secretion of aldosterone by adrenal cortex leading to vasopressor activity. Thus role of these ACE inhibitors is to inhibit the last step of the biosynthesis of angiotensin II and therefore causing a general vasodilatation and lowering of blood pressure [1-3]. Atorvastatin calcium (AT) [4] is a lipid lowering drug [5, 6], used for treatment of hypercholesterolemia. Metoprolol succinate (MT) acts as a beta-adrenergic blocking agent, which reduces chest pain and lowers high blood pressure [2, 7]. The chemical structures of RM, AT and MT are shown in Fig. 1.

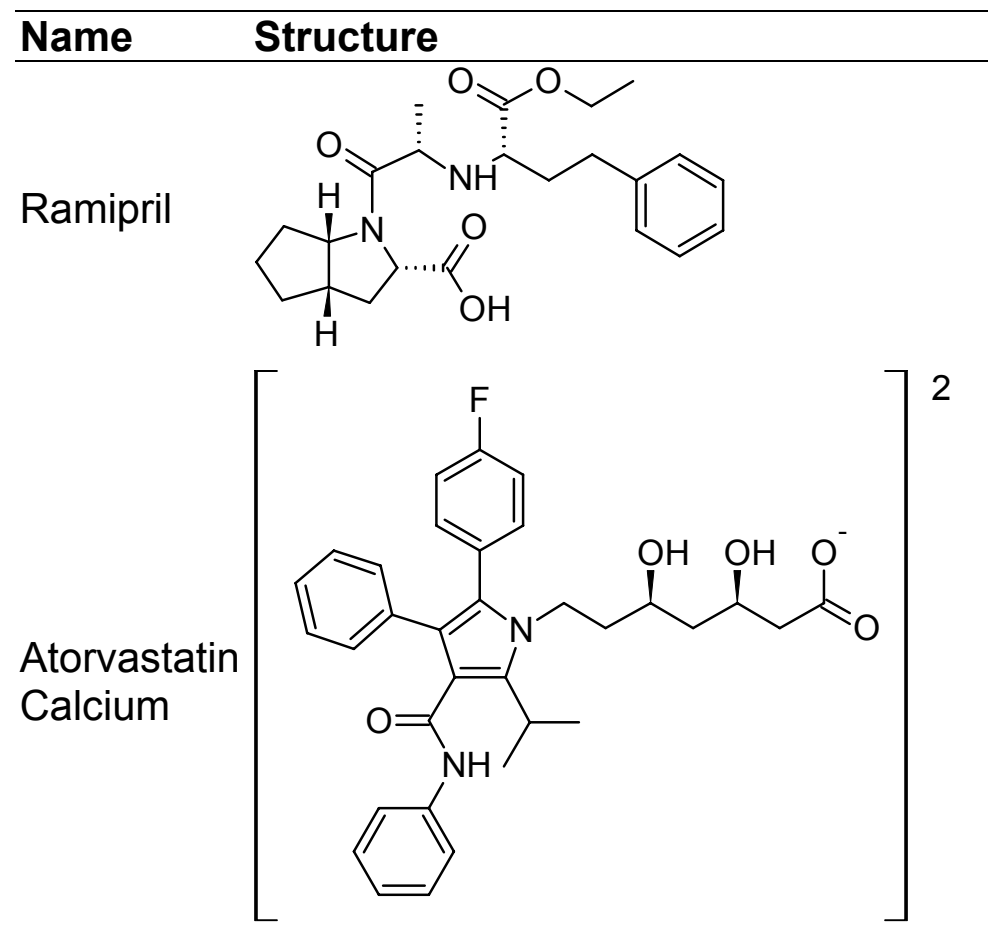

\section{IUPAC name}

(2S,3aS,6aS)-1-[(2S)-2-\{[(1S)-1(ethoxycarbonyl)-3-phenylpropyl]amino\}propanoyl]octahydrocyclopenta[b]pyrrole-2-carboxylic acid

calcium bis $\{(3 R, 5 R)-7-[2-(4-f l u o r o-$ phenyl)-5-(1-methylethyl)-3-phenyl4-(phenylcarbamoyl)-1 H-pyrrol-1-yl]3,5-dihydroxyheptanoate\}

1-[4-(2-methoxyethyl)phenoxy]-3[(1-methylethyl)amino]propan-2-ol butanedioate (2:1) (salt)<smiles>O=C(O)CCC(=O)O</smiles>

Fig.1. Chemical structures of RM, AT and MT

Many dosage forms of Metoprolol, Atorvastatin and Ramipril are available in market as a single or as combination dosage form with other drugs for effective therapy. As an individual molecule Atorvastatin shows effectiveness in lowering lipid levels in condition of dyslipidemia and metabolic syndrome. But since the hypercholesterolemia is also 
recognized as a causative factor in the development of atherosclerosis and hypertension, treatment with a beta-adrenergic blocking agent Metoprolol which is known to reduce the chest pain and lowering the high blood pressure also have antiatherosclerotic effects and Ramipril ACE (angiotensin converting enzyme) will always be a beneficial point for the patients by controlling hypertension, angina associated with dyslipidemia and metabolic syndrome. Hence these three combination formula is developed as once daily dosage form.

Dr. Reddy's is the first pharmaceutical company to develop this unique three-in-one combination product containing RM, AT and MT which is unique and has got the approval from Drug Controller General of India (DCGI), the Brand name of the product is Reviro.

Literature survey revealed several analytical methods such as UV Spectrophotometer [8-10], Liquid Chromatography [11-24], HP-TLC [25], LC-MS [26], UPLC [27, 28] Spectrofluorimetry $[29,30]$ have been reported for the determination of Metoprolol, Atorvastatin and Ramipril individually and in combination with different pharmaceutical dosage forms and biological samples [31]

Till date, to the best of our knowledge, no method has been reported in the literature for simultaneous determination of MT, AT and RM in oral dosage formulation. It is felt necessary to develop a stability indicating assay method for three compounds simultaneously.

Metoprolol impurity $\mathrm{C}$ is official in British Pharmacopoeia [32], Metoprolol diol impurity is a degradation product identified and completely characterized by using IR, Mass and NMR. Ramipril impurities D, E and $\mathrm{K}$ are official in British Pharmacopoeia [33]. Atorvastatin impurities lactone and hydroxyl epoxy oxazinine are the degradation products, isolated and characterized inhouse by using IR, Mass and NMR.

\section{Results and Discussion}

\section{Optimization of chromatographic conditions}

The HPLC method is optimized with a view to develop a stability indicating Assay. A stability-indicating assay method should accurately measure the active ingredients, without interference from degradation products, process impurities, excipients, or other potential impurities. The key objective of the method is to get the separation of all potential impurities of MT, AT and RM from their analyte peaks. Pure drug along with its related impurities were injected in Ramipril capsules BP method, it was observed that Atorvastatin peak shape is not symmetric and Atorvastatin major degradants Lactone and Hydroxyl epoxy oxazinine eluted after $20 \mathrm{~min}$. Subsequently Metoprolol tablets USP method was evaluated for separation of RM, AT and MT and its respective impurities. In the metoprolol method, the Atorvastatin peak eluted at $91 \mathrm{~min}$ and also peak fronting is observed for Ramipril, Atorvastatin peaks. 


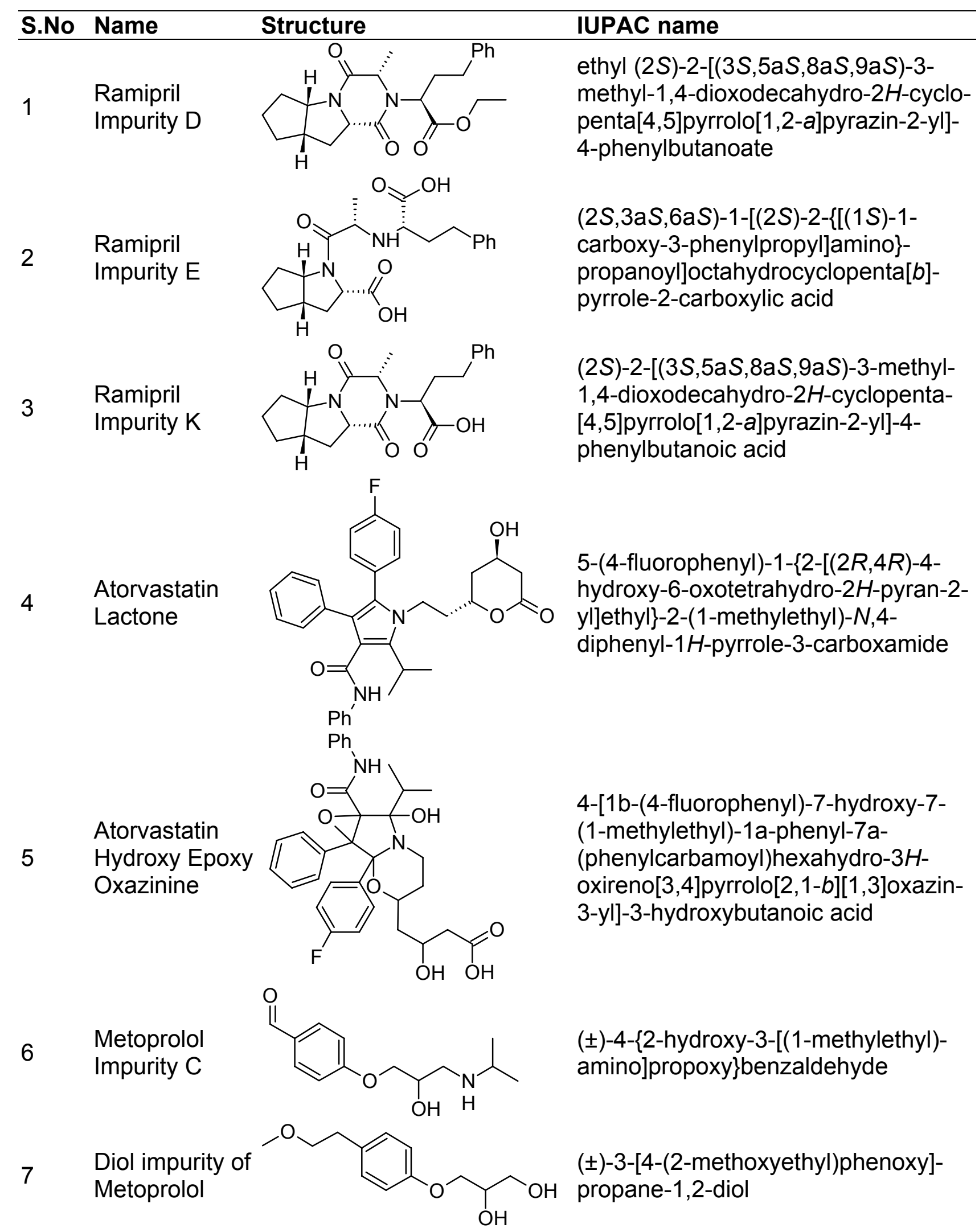

Fig. 2. Chemical structures of impurities of RM, AT and MT 
To develop a new method, the pure drug along with its related impurities were injected in different solvent systems containing sodium lauryl sulfate and orthophosphoric acid along with various ratios of organic modifiers acetonitrile and methanol on a C8 column. The impurities and degradants pertaining to RM, AT and MT active moieties were monitored at wavelength of $210 \mathrm{~nm}$. Further, $0.06 \%$ ortho phosphoric acid in Milli-Q water was used as buffer having an ion pair reagent, $0.045 \mathrm{M}$ sodium lauryl sulfate in the mobile phase to achieve effective separation between impurities and the analyte peaks. Buffer and acetonitrile in the ratio $50: 50$ at $1.0 \mathrm{ml} / \mathrm{min}$ flow at ambient temperature; it was observed that impurity $E$ and impurity $D$ peaks of Ramipril were merging with Metoprolol and Atorvastatin peaks. Modification of the buffer and acetonitrile ratio to 55:45 resulted the separation of impurity $E$ and impurity $D$ from Metoprolol and Atorvastatin peaks, but Ramipril peak was asymmetric i.e. peak tailing observed more than 2.0. The increase in the column temperature from ambient to $40^{\circ} \mathrm{C}$ resulted in achieving the peak symmetry and the separation all three analyte peaks AT, RM and MT from impurity peaks, but the observed runtime is more i.e. 45 min.

To reduce the runtime further, the above HPLC method is verified in UPLC using Zorbax® Eclipse plus-C8, $2.1 \mathrm{~mm} \times 50 \mathrm{~mm}, 1.8 \mu \mathrm{m}$ with flow rate of $0.6 \mathrm{ml} / \mathrm{min}$. On UPLC, the runtime is reduced to 10 minutes but the peak symmetry was failing for Metoprolol peak i.e. tailing more than 2.0. To improve the peak symmetry for MT, column was changed to Zorbax® XDB-C18, $4.6 \mathrm{~mm} \times 50 \mathrm{~mm}, 1.8 \mu \mathrm{m}$ with a flow rate $1.0 \mathrm{ml} / \mathrm{min}$, and column temperature is maintained at $55^{\circ} \mathrm{C}$. The chromatographic separation was achieved by following isocratic program using buffer as $0.06 \%$ ortho phosphoric acid in Milli $Q \circledR$ water having an ion pair reagent $0.045 \mathrm{M}$ sodium lauryl sulfate; buffer and acetonitrile in the ratio of 50:50 (v/v). The retention times of MT, AT and RM are $1.324 \mathrm{~min}, 2.148 \mathrm{~min}$ and 2.684 min respectively. This method is capable to separate all impurities (two known degradants of Atorvastatin, four known degradants of Ramipril and two known degradants of Metoprolol) from its analyte peaks within 5 minutes.

The typical overlay chromatogram of blank and standard is shown in Fig. 3. The typical overlay chromatogram of placebo and test is shown in Fig. 4. The Spiked chromatogram of AT, RM and MT along with impurities is shown in Fig. 5.

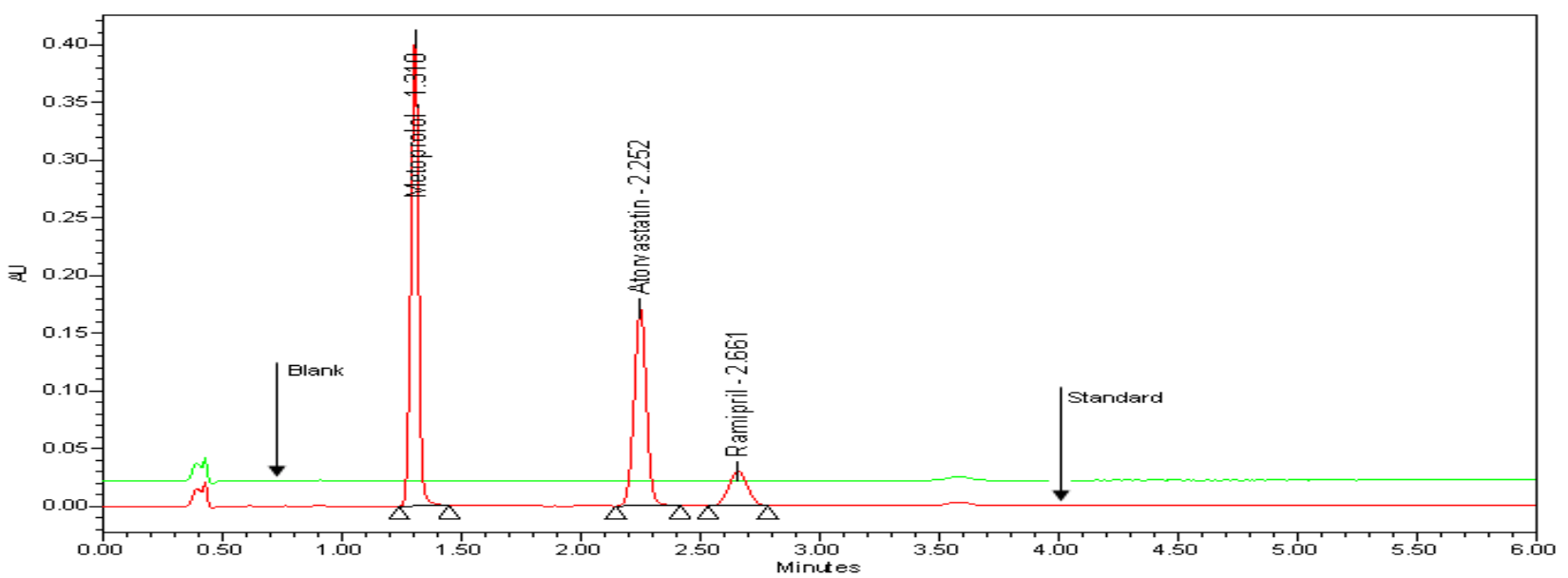

Fig. 3. Overlay chromatogram of blank and standard, extracted at 210nm for RM, AT and MT 


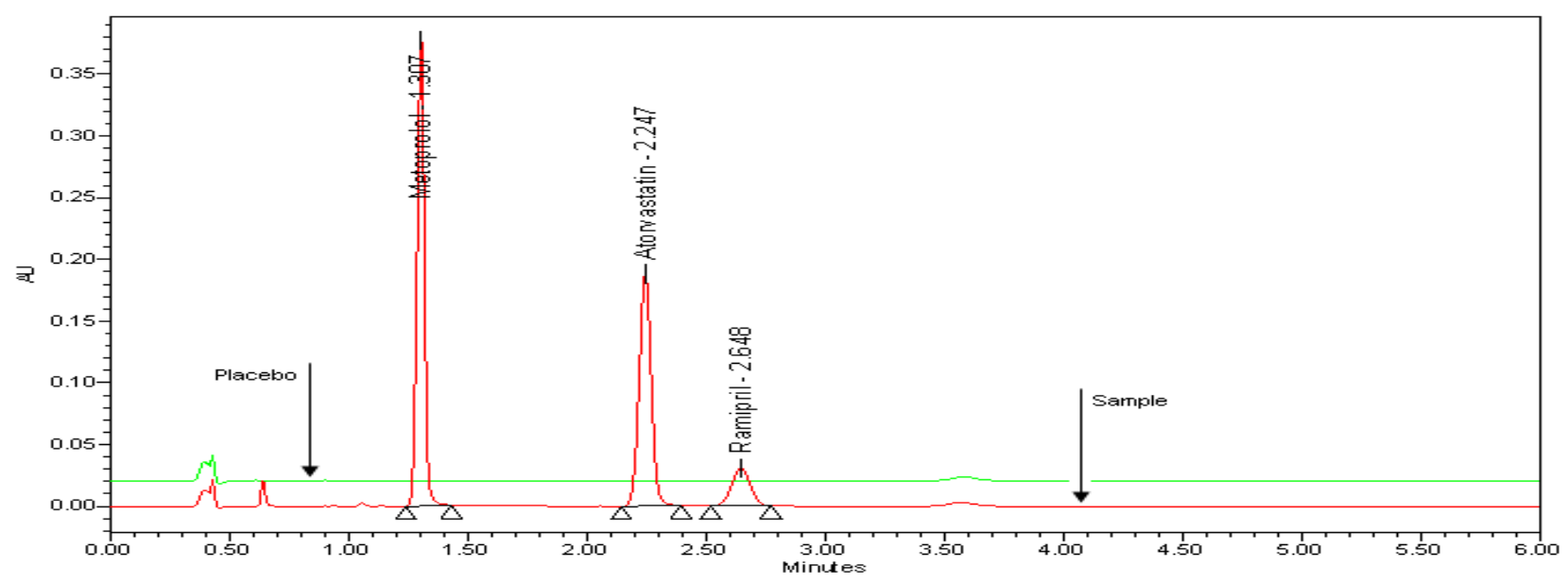

Fig. 4. Overlay chromatogram of Placebo and Test, extracted at 210nm for RM, AT and MT

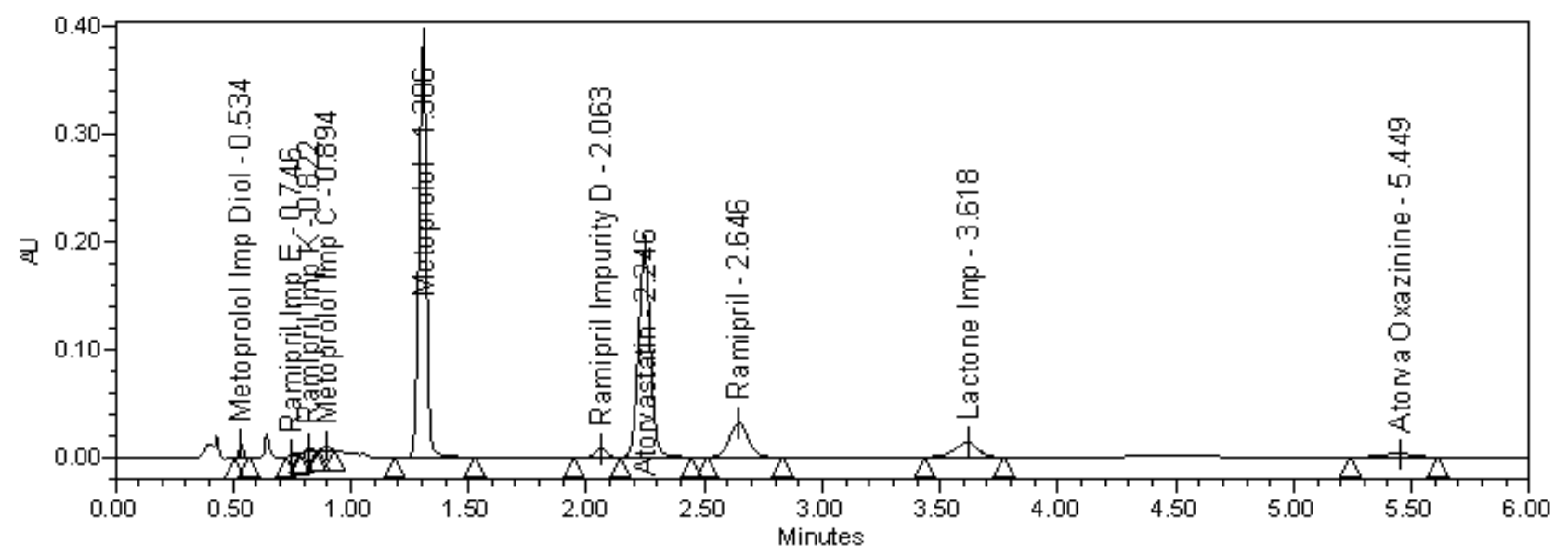

Fig. 5. Spiked chromatogram of AT, RM and MT along with impurities.

The system suitability parameters (see Table 1) indicate that the method meets the preliminary requirements and hence ready to be subjected for validation.

Tab. 1. System suitability results

\begin{tabular}{llll}
\hline System suitability parameters & Metoprolol & Atorvastatin & Ramipril \\
\hline Retention times min & 1.310 & 2.252 & 2.661 \\
Theoretical plates & 7638 & 8581 & 4958 \\
Asymmetric factor & 1.5 & 1.1 & 1.1 \\
Resolution & - & 10 & 4
\end{tabular}

The details of method validation, as per ICH guidelines [34] are presented in the following sections. 


\section{Method Validation}

\section{Specificity}

The samples have been subjected to degradation such as refluxed with $0.1 \mathrm{~N} \mathrm{HCl}$ for 30 min at $60^{\circ} \mathrm{C}$, refluxed with $0.1 \mathrm{~N} \mathrm{NaOH}$ for $30 \mathrm{~min}$ at $60^{\circ} \mathrm{C}$, refluxed with $3 \%$ peroxide for $30 \mathrm{~min}$ at $60^{\circ} \mathrm{C}$, exposed to dry heat at $105^{\circ} \mathrm{C}$ for $15 \mathrm{~h}$, refluxed for 1 hour at $60^{\circ} \mathrm{C}$ in water, exposed to visible light of 1.2 million lux hours, UV light of 200 watt hours $\mathrm{m}^{-2}$ and exposed to $90 \%$ relative humidity at $25^{\circ} \mathrm{C}$ for 7 days (Table 2 ).

Tab. 2. Forced degradation data

\begin{tabular}{|c|c|c|c|}
\hline \multirow{2}{*}{ Degradation conditions } & \multicolumn{3}{|c|}{$\%$ Degradation } \\
\hline & Metoprolol & Atorvastatin & Ramipril \\
\hline Exposed to Visible light for about $1,200 \mathrm{~K}$ lux & 0.2 & 0.9 & 1.5 \\
\hline Exposed to UV for 200 Watt hours $\mathrm{m}^{-2}$ & 0.1 & 0.6 & 0.3 \\
\hline $\begin{array}{l}\text { Exposed to humidity at } 25^{\circ} \mathrm{C}, 90 \% \mathrm{RH} \text { for } \\
\text { about } 7 \text { days }\end{array}$ & 0.0 & 1.2 & 1.4 \\
\hline $\begin{array}{l}\text { Refluxed with purified water for about } 1 \text { hour } \\
\text { at } 60^{\circ} \mathrm{C}\end{array}$ & 0.1 & 0.9 & 0.7 \\
\hline $\begin{array}{l}\text { Refluxed with } 0.1 \mathrm{~N} \mathrm{HCl} \text { solution for about } \\
30 \text { min at } 60{ }^{\circ} \mathrm{C}\end{array}$ & 0.0 & 1.2 & 2.7 \\
\hline $\begin{array}{l}\text { Refluxed with } 0.1 \mathrm{~N} \mathrm{NaOH} \text { solution for about } \\
30 \text { min at } 60^{\circ} \mathrm{C}\end{array}$ & 0.1 & 0.7 & 2.6 \\
\hline $\begin{array}{l}\text { Refluxed with } 3 \% \mathrm{H}_{2} \mathrm{O}_{2} \text { solution for about } 30 \\
\text { min at } 60{ }^{\circ} \mathrm{C}\end{array}$ & 0.3 & 2.2 & 4.8 \\
\hline $\begin{array}{l}\text { Exposed to dry heat for about } 15 \text { hours at } \\
105^{\circ} \mathrm{C}\end{array}$ & 0.4 & 32.3 & 33.5 \\
\hline
\end{tabular}

Degradation was not observed in visible light, UV, humidity and water hydrolysis stress studies. Significant degradation was not shown in acid hydrolysis, base hydrolysis and oxidative conditions. However, thermal stress showed significant degradation. It is interesting to note that all the peaks due to degradation are well resolved from the peaks of MT, AT \&RM (Fig. 6). Further the peak purity of MT, AT \& RM was found to be homogeneous based on the evaluation parameters such as purity angle and purity threshold using Waters Empower Networking Software. The verification of peak purity indicates that there is no interference from degradants, facilitating error-free quantification of MT, AT and RM. Thus, the method is considered to be "Stability-indicating".

\section{Linearity}

The linear regression analysis of MT, AT and RM was constructed by plotting the concentration of each analyte versus peak area. The calibration curves were linear in the range of $105-840 \mu \mathrm{g} / \mathrm{ml}, 20-160 \mu \mathrm{g} / \mathrm{ml}$ and $10-80 \mu \mathrm{g} / \mathrm{ml}$ for MT, AT and RM respectively. The linear regression equations are given below.

$$
\begin{aligned}
& \text { MT: } Y=2033.264 \text { conc. }+5139.971\left(r^{2}=0.9996\right) \\
& \text { AT: } Y=7928.515 \text { conc. }+5806.824\left(r^{2}=0.9998\right) \\
& \text { RM: } Y=4045.254 \text { conc. }+339.373\left(r^{2}=0.9995\right)
\end{aligned}
$$




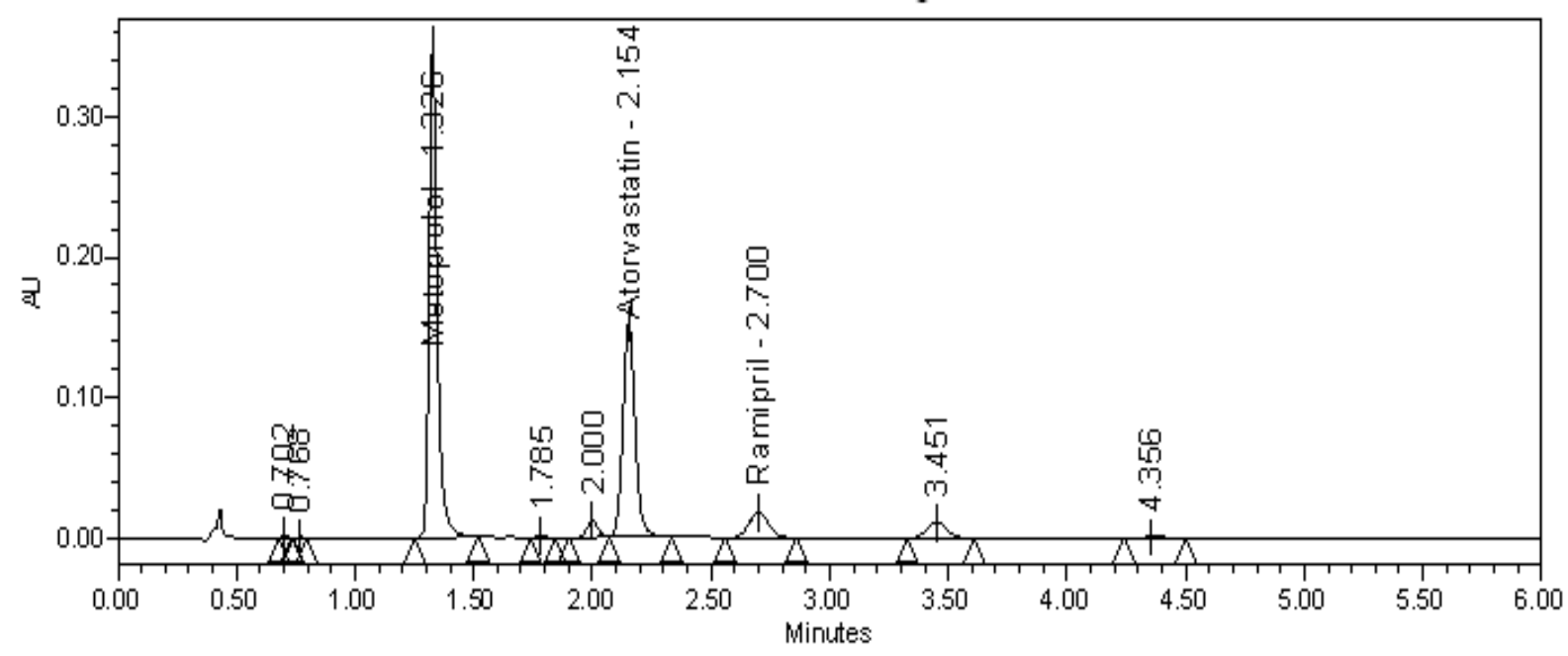

Purity Plot

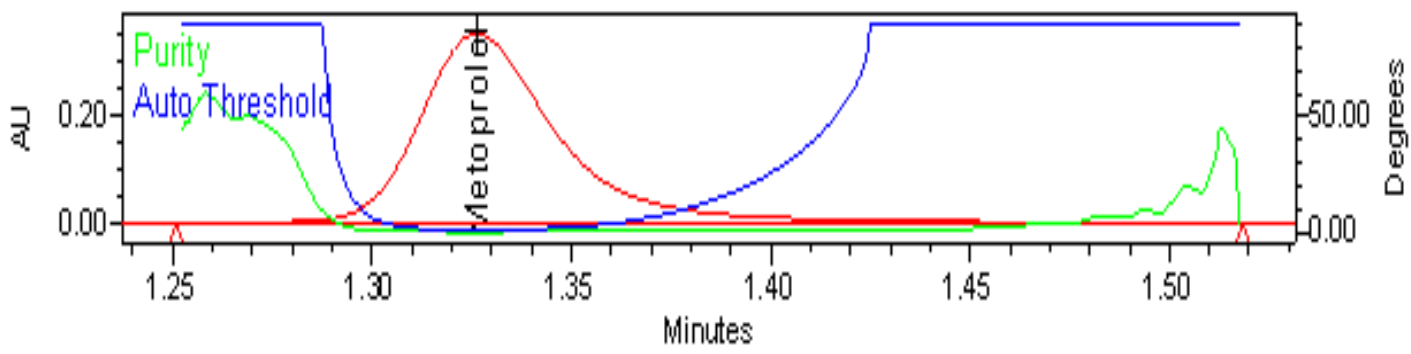

Purity Plot

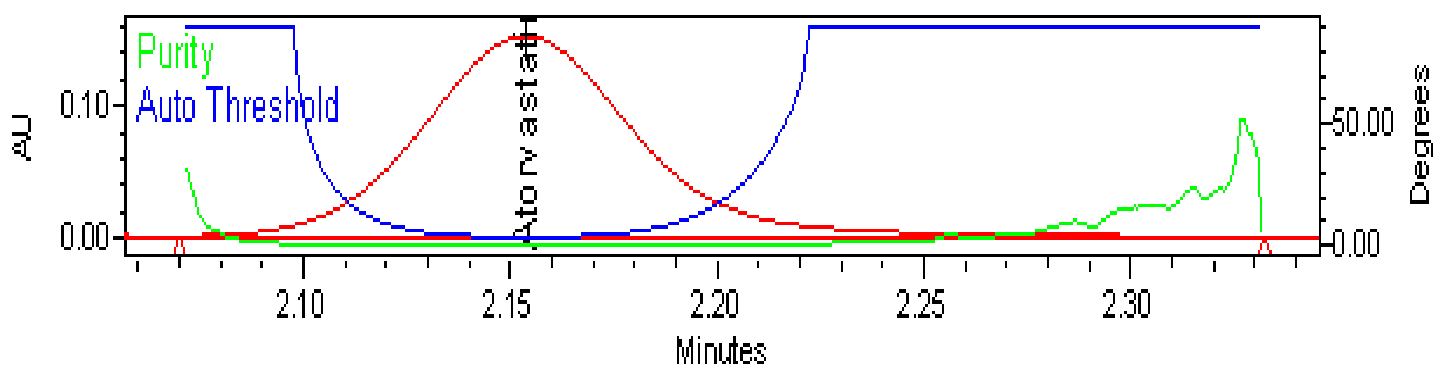

Purity Plot

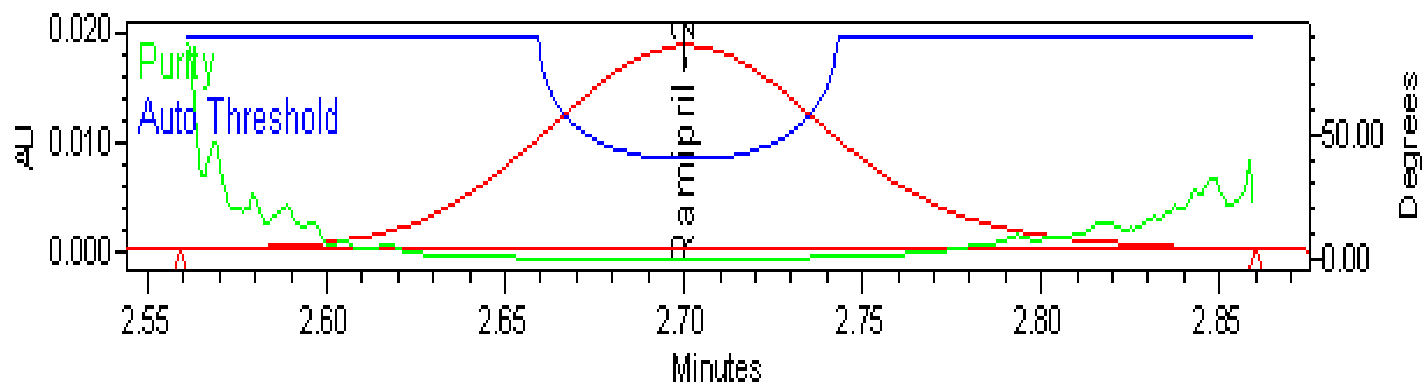

- Purity

- Auto Threshold

Fig. 6. Chromatogram and purity plots of heat stressed MT, AT and RM capsules test 


\section{Precision}

The precision of test method was evaluated by analyzing six samples of MT, AT and RM capsules. The \% RSD of assay of three analytes during precision was found to be less than $2 \%$. The results are shown in Table 3, which indicates that the method is precise.

Tab. 3. Precision of the method

\begin{tabular}{lccc}
\hline \multirow{2}{*}{ S.NO. } & \multicolumn{3}{c}{ \% Assay } \\
\cline { 2 - 4 } & Metoprolol & Atorvastatin & Ramipril \\
\hline 1. & 101.9 & 102.4 & 102.2 \\
2. & 101.5 & 101.7 & 100.4 \\
3. & 102.0 & 102.0 & 101.7 \\
4. & 101.3 & 102.3 & 102.3 \\
5. & 102.3 & 102.1 & 100.4 \\
6. & 102.3 & 102.3 & 101.5 \\
Average & 101.9 & 102.1 & 101.4 \\
\% RSD & 0.4 & 0.3 & 0.8
\end{tabular}

Accuracy

Recovery study of MT, AT and RM from spiked placebo is conducted. Samples are prepared by mixing placebo with MT, AT and RM raw material equivalent to about $20 \%$, $50 \%, 80 \%, 100 \%$, and $160 \%$ of the assay of nominal sample concentration. Sample solutions are prepared in triplicate for each spike level as described in the sample preparation. The \% mean recoveries of individual analyte from formulation samples were found to be satisfactory. The summary of \% recovery was mentioned in Table 4.

Tab. 4. Accuracy of the method

\begin{tabular}{|c|c|c|c|c|c|c|c|c|c|}
\hline $\begin{array}{l}\text { Accu- } \\
\text { racy } \\
\text { level }\end{array}$ & $\begin{array}{c}\text { MT } \\
\text { Added } \\
\text { (mg) }\end{array}$ & $\begin{array}{c}\text { MT } \\
\text { Recov. }^{a} \\
(\%)\end{array}$ & $\begin{array}{c}\text { Mean } \\
\text { MT } \\
(\%)\end{array}$ & $\begin{array}{c}\text { AT } \\
\text { Added } \\
\text { (mg) }\end{array}$ & $\begin{array}{c}\text { AT } \\
\text { Recov. }^{a} \\
(\%)\end{array}$ & $\begin{array}{c}\text { Mean } \\
\text { AT } \\
(\%)\end{array}$ & $\begin{array}{c}\text { RM } \\
\text { Added } \\
\text { (mg) }\end{array}$ & $\begin{array}{c}\text { RM } \\
\text { Recov. }^{a} \\
(\%)\end{array}$ & $\begin{array}{c}\text { Mean } \\
\text { RM } \\
(\%)\end{array}$ \\
\hline $20 \%$ & 99.960 & 101.0 & & 20.565 & 101.6 & & 10.283 & 100.6 & \\
\hline $50 \%$ & 246.954 & 101.8 & & 52.036 & 100.2 & & 26.018 & 102.0 & \\
\hline $80 \%$ & 392.084 & 102.1 & 101.8 & 80.700 & 102.5 & 101.8 & 40.350 & 101.4 & 101.2 \\
\hline $100 \%$ & 495.629 & 102.1 & & 102.731 & 102.4 & & 51.366 & 101.0 & \\
\hline $160 \%$ & 783.014 & 102.0 & & 162.870 & 102.4 & & 81.435 & 101.0 & \\
\hline
\end{tabular}

${ }^{\mathrm{a}}$ Mean for three determinations at each level.

\section{Robustness}

To determine the robustness of the developed method, experimental conditions are deliberately altered one factor after the other. The effect of change in flow rate $( \pm 0.2 \mathrm{ml})$, organic phase composition $( \pm 5 \%)$ and column temperature $\left( \pm 5^{\circ} \mathrm{C}\right)$ on the retention time, resolution and asymmetric factor were studied. In all the studies the resolution between MT and AT, AT and RM peaks is greater than 2.5, asymmetric factor is less than 2.0 and theoretical plates are more than 2500 for MT, AT and RM peaks, which illustrates the robustness of the method. 


\section{Test solution stability}

The bench top solution stability of test preparation and standard preparation of MT, AT and RM was carried out up to 48 hours, no significant change is observed in \% assay of MT, AT and RM. Hence the test solutions are stable upto $48 \mathrm{hrs}$.

\section{Experimental}

\section{Reagents and Materials}

Active pharmaceutical ingredient of MT, AT and RM and it's impurities were procured from bulk manufacturers of Dr Reddy's Laboratories. Capsule dosage form developed by Dr Reddy's Laboratories, India. HPLC grade acetonitrile was purchased from Merck, Germany. Analytical reagent sodium lauryl sulfate and ortho phosphoric acid were purchased from Merck, Germany. High pure water was prepared by using Millipore Milli $\mathrm{Q}$ plus purification system.

\section{Apparatus and chromatographic conditions}

The Waters Acquity UP-LC system with a photo diode array detector was used for method development, validation and forced degradation studies. The output signal was monitored and processed using Empower software.

\section{Chromatographic conditions}

The chromatographic column used was a Zorbax® XDB-C18, $4.6 \mathrm{~mm}$ * $50 \mathrm{~mm}, 1.8 \mu \mathrm{m}$ particles. The buffer used was $0.0045 \mathrm{M}$ of sodium lauryl sulfate with $0.06 \%(1 \mathrm{gm})$ ortho phosphoric acid. Buffer and acetonitrile in the ratio of 50:50 was used as mobile phase. The flow rate of the mobile phase was $1.0 \mathrm{ml} / \mathrm{min}$. The column was maintained at $55^{\circ} \mathrm{C}$ and the wavelength of $210 \mathrm{~nm}$ for detection of MT, RM and AT. The injection volume was $2 \mu \mathrm{L}$.

\section{Preparation of standard solution}

Standard solution was prepared in methanol containing $420 \mathrm{\mu g} \mathrm{ml}^{-1}$ of Metoprolol succinate, $80 \mu \mathrm{g} \mathrm{ml}^{-1}$ of Atorvastatin and $40 \mu \mathrm{g} \mathrm{ml}^{-1}$ of Ramipril. Purity of standards used is $99.3 \%$ as Metoprolol Succinate, $99.3 \%$ as Atorvastatin and $99.8 \%$ as Ramipril.

\section{Preparation of Test solution}

Contents of 10 capsules along with capsule shell (each capsule containing $47.5 \mathrm{mg} \mathrm{MT}$, $10 \mathrm{mg}$ AT and $5 \mathrm{mg} \mathrm{RM}$ ) was transferred into $250 \mathrm{ml}$ dried volumetric flask, $150 \mathrm{ml}$ of methanol is added and sonicated for $30 \mathrm{~min}$ with intermediate shaking (maintain the sonicator temperature between $20^{\circ} \mathrm{C}-25^{\circ} \mathrm{C}$ ), followed by shaking of $15 \mathrm{~min}$. The flask is to allowed cool down to room temperature and then diluted to volume with methanol. A part of solution is centrifuged to get clear solution. Further $5 \mathrm{ml}$ of clear centrifuged solution is transferred into $25 \mathrm{ml}$ volumetric flask and diluted to volume with methanol to obtain sample solution concentration of $420 \mu \mathrm{g} / \mathrm{ml}, 80 \mu \mathrm{g} / \mathrm{ml}$ and $40 \mu \mathrm{g} / \mathrm{ml}$ respectively.

\section{Conclusions}

The developed chromatographic assay fulfilled all the requirements to be identified as reliable and feasible method, including accuracy, linearity, recovery and precision data. It 
is a highly specific and precise analytical procedure and its chromatographic run time of six minutes allows the analysis of a large number of samples in a short period of time. Therefore, this HPLC method can be used as a routine sample analysis as well as stability testing. The method validation shows satisfactory data for all the method validation parameters tested. The developed method is stability-indicating and can be used for quantifying Metoprolol, Atorvastatin and Ramipril in capsule dosage form and their combinations (i.e. $M T+A T ; M T+R M, A T+R M$ and $A T+R M+M T$ ).

\section{Acknowledgements}

The authors wish to thank the management of Dr. Reddy's group for supporting this work. Authors wish to acknowledge the formulation development group for providing the samples for our research. We would also like to thank colleagues in bulk manufacturers for providing chemicals and impurity standards for our research work.

Dr. Reddy's internal publication number for this manuscript is PUB-00033-10.

\section{Authors' Statement}

\section{Competing Interests}

The authors declare no conflict of interest.

\section{References}

[1] Yusuf S, Sleight P, Pogue J, Bosch J, Davies R, Dagenais G.

Effects of an angiotensin-converting-enzyme inhibitor, ramipril, on cardiovascular events in high-risk patients. The Heart Outcomes Prevention Evaluation Study Investigators.

N Engl J Med. 2000; 342(3): 145-153. doi:10.1056/NEJM200001203420301

[2] Arnold JM, Yusuf S, Young J, Mathew J, Johnstone D, Avezum A, Lonn E, Pogue J, Bosch J. Prevention of Heart Failure in Patients in the Heart Outcomes Prevention Evaluation (HOPE) Study. Circulation. 2003; 107: 1284-1290. doi:10.1161/01.CIR.0000054165.93055.42

[3] Dagenais GR, Yusuf S, Bourassa MG, Yi Q, Bosch J, Lonn EM, Kouz S, Grover J; HOPE Investigators.

Effects of Ramipril on Coronary Events in High-Risk Persons: Results of the Heart Outcomes Prevention Evaluation Study.

Circulation. 2001; 104: 522-526.

doi:10.1161/hc3001.093502

[4] Budavari, S, Eds, In.

An Encyclopedia of Chemicals, Drugs and Biologicals.

The Merck Index; 12 th Edn., Merck \& Co., Inc., Whitehouse Station, NJ. 1996; 146.

[5] Reynolds JEF.

Martindale: The Extra Pharmacopoeia; 31st Edn., Royal Pharmaceutical Society, London. 1996; 1302.

[6] Reich JW.

In: Gennaro AR, Ed., Remington.

The Science and Practice of Pharmacy, Vol-II.

20 th Edn, Mack Publishing Company, Easton, PA. 2000; 1294.

[7] The Merck Index (14th Ed.). 2006; 493 \& 6149. 
[8] Thamake SL, Jadhav SD, Pishawikar SA.

Development and validation of method for simultaneous estimation of Atorvastatin Calcium and Ramipril from capsule dosage form by first order derivative spectroscopy.

Asian J Res Chem. 2009; 2: 52-53.

[9] Yogesh BZ, Santosh RK, Simpi CC.

Simultaneous Estimation of Atorvastatin and Ramipril by First Derivative Spectrophotometric method. J Pharm Res. 2009; 2: 874-877.

[10] Bharat GC, Ashok BP.

Simultaneous Spectrophotometric Estimation of Atorvastatin Calcium and Amlodipine Besylate in tablet dosage forms.

Int J ChemTechRes. 2010; 2: 633-639.

[11] Brijesh S, Patel DK, Ghosh SK.

Development of Reverse-Phase HPLC Method for Simultaneous Analysis of Metoprolol Succinate and Hydrochlorothiazide in a Tablet Formulation.

Trop J Pharm Res. 2009; 8: 539-543.

[12] Phale MD, Hamrapurkar PD.

A Validated and Simplified RP-HPLC of Metoprolol Succinate from Bulk Drugs.

Asian J Res Chem. 2009; 2: 119-122.

[13] Sohan SC, Mohammed Imran, Dinesh MS.

RP-HPLC method for simultaneous estimation of Amlodipine and Metoprolol in tablet formulation.

Asian J Pharm. 2008; 2: 232-234.

doi:10.4103/0973-8398.45037

[14] LI Qin, Wang R.

Simultaneous analysis of Tramadol, Metoprolol and their metabolites in human plasma and urine by high performance liquid chromatography.

Chin Med J. 2006; 119: 2013-2021.

PMid:17199947

[15] Dongre VG, Shah SB, Karmuse PP, Phadke M, Jadhav VK.

Simultaneous determination of Metoprolol succinate and Amlodipine besylate in pharmaceutical dosage form by HPLC.

J Pharm Biomed Anal. 2008; 46: 583-586.

doi:10.1016/j.jpba.2007.11.006

[16] Baranowska I, Wilczek A.

Simultaneous RP-HPLC Determination of Sotalol, Metoprolol, $\alpha$-Hydroxymetoprolol, Paracetamol and Its Glucuronide and Sulfate Metabolites in Human Urine.

Anal Sci. 2009; 25: 769-772.

doi:10.4103/0250-474X.25738

[17] Shah DA, Bhatt KK, Mehta RS, Shankar MB, Baldania SL.

RP-HPLC method for the determination of Atorvastatin calcium and Nicotinic acid in combined tablet dosage form.

Indian J Pharm Sci. 2007; 69: 700-703.

doi:10.4103/0250-474X.25738

[18] Rajeswari KR, Sankar GG, Rao AL, Seshagirirao JVLN

RP-HPLC method for the simultaneous determination of Atorvastatin and Amlodipine in tablet dosage form.

Indian J Pharm Sci. 2006; 68: 275-277.

doi:10.4103/0250-474X.25738

[19] Lucie N, Dalibor S, Petr S.

HPLC methods for the determination of Simvastatin and Atorvastatin.

Trends Anal Chem. 2008; 27: 352-367.

doi:10.1016/j.trac.2008.01.013 
[20] Zahid Z, Farooqui MN, Mangle AA, Nikalje AG.

Stability-indicating high performance liquid chromatographic determination of Atorvastatin calcium in pharmaceutical dosage form.

Afr J Pharm Pharmacol. 2008; 2: 204-210.

[21] Belal F, Al-Zaagi IA, Gadkariem EA, Abounassif MA.

A stability-indicating LC method for the simultaneous determination of Ramipril and

Hydrochlorothiazide in dosage forms.

J Pharm Biomed Anal. 2001; 24: 335-342.

doi:10.1016/S0731-7085(00)00474-X

[22] Kurade VP, Pai MG, Gude R.

RP-HPLC estimation of Ramipril and Telmisartan in tablets.

Indian J Pharm Sci. 2009; 71: 148-151.

doi:10.4103/0250-474X.54283

[23] Lincy J, Mathew G, Venkata RRB.

Simultaneous estimation of Atorvastatin and Ramipril by RP-HPLC and Spectroscopy.

Pak J Pharm Sci. 2008; 21: 282-284.

PMid:18614425

[24] Hiral JP, Bhanubhai NS, Natvarlal JP, Ishwarsinh SR, Bhavesh HP.

Simultaneous Estimation of Atorvastatin Calcium, Ramipril and Aspirin in Capsule Dosage Form by

RP-LC.

Chromatographia. 2009; 69: 91-95.

doi:10.1365/s10337-008-0831-z

[25] Panchal HJ, Suhagia BN, Patel NJ, Patel SSK.

Simultaneous HPTLC analysis of Atorvastatin calcium, Ramipril, and Aspirin in a capsule dosage form. J Planar Chromatogr Mod TLC. 2009; 22: 265-271.

doi:10.1556/JPC.22.2009.4.5

[26] Sarkar AK, Ghosh D, Das A, Selvan PS, Gowda KV, Mandal U, Bose A, Agarwal S, Bhaumik U, Pal TK.

Simultaneous determination of Metoprolol succinate and Amlodipine besylate in human plasma by liquid chromatography-tandem mass spectrometry method and its application in bioequivalence study. J Chromatogr B. 2008; 873: 77-85.

doi:10.1016/j.jchromb.2008.07.040

[27] Kadav AA, Vora DN.

Stability-indicating UPLC method for simultaneous determination of Atorvastatin, Fenofibrate and their degradation products in tablets.

J Pharm Biomed Anal. 2008; 48: 120-126.

doi:10.1016/j.jpba.2008.05.018

[28] Novakova L, Vickova H, Satinsky D, Sadilek P, Solichova D, Blaha M, Blaha V, Solich P. Ultra high performance liquid chromatography tandem mass spectrometric detection in clinical analysis of Simvastatin and Atorvastatin.

J Chromatogr B. 2009; 877: 2093-2103.

doi:10.1016/j.jchromb.2009.05.052

[29] Attia MS.

Spectrofluorimetric assessment of Ramipril using optical sensor Samarium ion-doxycycline complex doped in sol-gel matrix.

J Pharm Biomed Anal. 2010; 51: 7-11.

doi:10.1016/j.jpba.2009.08.017

[30] Zhang Y, Wu HL, Xia AL, Zhu SH, Han QJ, Yu RQ.

Fluorescence determination of Metoprolol in human plasma by trilinear decomposition-based calibration techniques.

Anal Bioanal Chem. 2006; 386: 1741-1748.

doi:10.1007/s00216-006-0732-7 
[31] Murray GJ, Danaceau JP.

Simultaneous extraction and screening of diuretics, beta-blockers, selected stimulants and steroids in human urine by HPLC-MS/MS and UPLC-MS/MS.

J Chromatogr B. 2009; 877: 3857-3864.

doi:10.1016/j.jchromb.2009.09.036

[32] British Pharmacopoeia, Medicinal and Pharmaceutical Substances 2009; I and II: 3933-3937.

[33] British Pharmacopoeia, Medicinal and Pharmaceutical Substances 2009; I and II: 5160-5167.

[34] ICH - Q2 (R1) (2005).

Guideline on Validation of Analytical Procedure. Text and Methodology. 